\title{
Az experimentális intracelluláris akciós potenciáltól a humán intrakardiális szív-elektrofiziológián alapuló kezelésig (aritmiamútét, ICD, transzkatéteres abláció)
}

\author{
Borbola József \\ Gottsegen György Országos Kardiológiai Intézet, Felnőtt Kardiológiai Osztály, Budapest \\ Levelezési cím: Dr. Borbola József PhD, 1450 Budapest, Pf. 88. E-mail: borbola@kardio.hu
}

Első egyetemi tanítómesterem, mentorom, atyai jóbarátom, prof. dr. Papp Gyula Széchenyi-díjas akadémikus 80 . születésnapjára sok szeretettel és tisztelettel ajánlja az egyik legrégebbi tanítványa.

A szerző áttekinti orvosi pályafutását, amely a Szegedi Orvostudományi Egyetem Gyógyszertani Intézetében kezdődött (1970). A Szív-elektrofiziológiai Munkacsoportban dr. Papp Gyula irányítása mellett a magas szabadzsírsav-szint borjú Purkinje-rostra kifejtett direkt hatását vizsgálták az ún. zsírsavhipotézis kapcsán. Megállapították, hogy a magas szabadzsírsav-szint képes mélyrehatóan befolyásolni az ép Purkinje-rost elektromos aktivitását. Orvosi, klinikai munkája Budapesten, az Országos Kardiológiai Intézetben folytatódott (1976-). Kardiológusi tevékenysége mellett korán elsajátította az intrakardiális szív-elektrofiziológia vizsgálómódszereit. Ezután számos új, intrakardiális szív-elektrofiziológián alapuló terápiás beavatkozást honosított meg elsőként hazánkban. Ehhez külföldi tanulmányútjai is hozzásegítették. 1990.06.25-én súlyos WPW-szindrómában sikeres aritmiamütétet, 1992.01.08-án együregü ICD (Medtronic 7217/B), majd 1997.11.21-én kétüregü ICD (Guidant AVII DR) implantációt végeztek. Alapítványi segítséggel transzkatéteres rádiófrekvenciás laboratóriumot alapítottak (1994), majd elvégezte az első hazai ablációs beavatkozást (1994.07.28.) WPW-szindrómában, majd ún. lassú-pálya ablációs modifikációt (1995.01.05.) AVNRT gyógyítására. Véleménye szerint a szegedi mikro szív-elektrofizológiai ismeretei, valamint nagyszerü tanítómesterének, prof. dr. Papp Gyula akadémikusnak folyamatos inspirációi nagymértékben hozzájárultak a klinikai szív-elektrofiziológián alapuló gyógyító beavatkozások első hazai sikeres elvégzéseihez.

Kulcsszavak: intracelluláris akciós potenciál, aritmiamütét, ICD, transzkatéteres rádiófrekvenciás abláció

From the experimental intracellular action potential to the clinical treatment based on human intracardiac electrophysiology (arrhythmia-surgery, ICD, transcatheter ablation)

A short review is provided of the author's medical carrier, which started at the Department of Pharmacology of Szeged Medical University (1970). In connection with the free fatty acid hypothesis, he studied the direct effects of the high free fatty acid level on the electrical activity of calf Purkinje fibres under the guidance of Julius Gy. Papp in the Working Group of Cardiac Electrophysiology. It was concluded that the electrical activity can be seriously altered by high free fatty acid level already in a normal Purkinje fibre. His clinical work, as a cardiologist, continued at the Hungarian Institute of Cardiology in Budapest (1976-). He became adept early at investigational methods of intracardiac electrophysiology besides his clinical works. Numerous new therapeutic approach has been introduced by him first in the country based on intracardiac electrophysiology. In 1990 they performed a successful arrhythmia-surgery in a patient with serious WPW syndrome, in 1992 they implanted the first ICD (VVICD) in the country, later in 1997 the first ICD of DDICD type. After the foundation of a transcatheter ablation laboratory (1994), he performed the first transcatheter ablation in a patient with serious WPW syndrome (1994), later he performed the first "slow-pathway" modification in AVNRT (1995).According to his opinion, his knowledge in cardiac microelectrophysiology learned in the years of Szeged and the continuous inspirations by his first university master went a long way towards the first therapeutic antiarrhythmic interventions in the country based on intracardiac electrophysiology.

Keywords: intracellular action potential, arrhythmia-surgery, ICD, transcatheter ablation 
A Szegedi Orvostudományi Egyetem elvégzése (1970) után az egyetem patinás Gyógyszertani Intézetébe kerültem, ahol szerencsémre a szívritmuszavarok kialakulásával és kezelésével experimentálisan foglalkozó Szív-elektrofiziológiai Munkacsoportba kaptam beosztást prof. dr. Szekeres László tanszékvezető igazgatótól. Az intézeti kutatóorvosi munkát prof. dr. Papp Gyula munkacsoport-vezető (akkoriban egyetemi adjunktus) irányításával kezdtem el, aki ebben az időben tért haza angliai ösztöndíjas munkájából. Az antiaritmiás gyógyszerek klasszifikációjáról híres Vaughan Williams EM. Intézetében (1968-69), Oxfordban nagy sikerrel tanulmányozta néhány béta-blokkoló, valamint a kísérletes hypo-, hyperthyreosis direkt szívhatásait új mikroelektrofiziológiai módszerekkel (1).

\section{Szegedi Orvostudományi Egyetem, Gyógyszertani Intézet (1970-1976)}

Az akkori klinikai kutatások kapcsán az 1970-es évek elején került előtérbe, hogy az akut szívizominfarktus
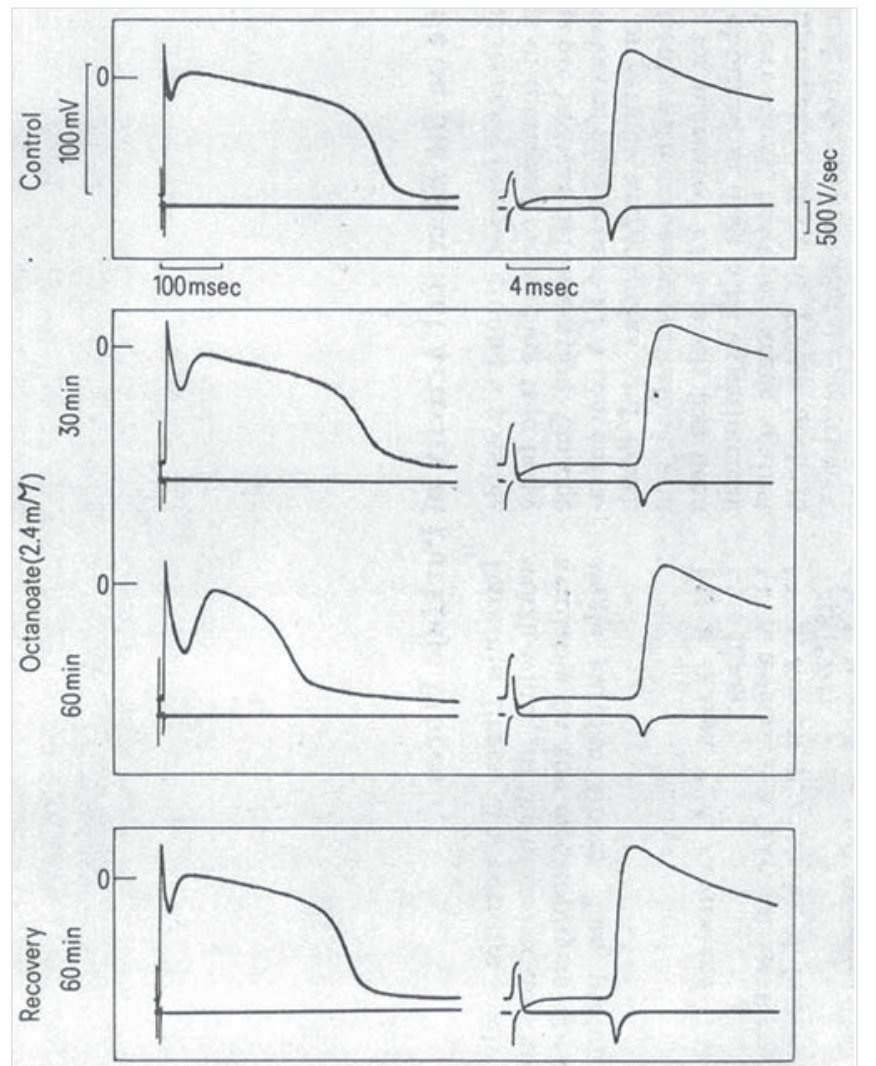

1. ÁBRA. Octanoat $(2,4 \mathrm{mmol} / \mathrm{l})$ hatása borjúszív Purkinje-rost intracelluláris ablációs potenciáljára. (Minden egyes felvételen: felső sugarakon: ingerbetörés és az intracelluláris akciós potenciál az oszcilloszkóp sugár lassú [baloldalon] és gyors [jobb oldalon] végigfutási sebessége mellett; alsó sugarakon: ingerbetörés és a depolarizáció maximális sebességével arányos differenciált jel, a közöttük lévő távolság az ingerületvezetési sebességgel arányos. 0: zéró potenciál. Hajtó frekvencia: 60/min.) korai időszakában a súlyos, nemritkán halálos kamrai ritmuszavarok kialakulását - többek között - a vér igen magas szabadzsírsav-szint (FFA) aritmogénnek vélt hatása idézné elő (ún. Kurien-Oliver-hipotézis) (2). Klinikaorientált kutatási témát keresve emiatt kezdtem el a magas FFA-szint direkt szívhatásait tanulmányozni kísérletes szív-elektrofiziológiai módszerekkel. Izolált nyúlszív-preperátumok extracelluláris elektrofiziológiai paraméterein (sinusfrekvencia, elektromos ingerküszöb, ingerületvezetési sebesség, effektív refrakter szak) és a kontraktilitást is vizsgálva kiderült, hogy az FFA-k (pl. az octanoat) erősen depresszív hatásúak az említett paraméterekre (3). Magával ragadó, inspiráló briliáns munkacsoportvezetőm az esti beszélgetések kapcsán azt javasolta, hogy borjú Purkinje-rost intracelluláris akciós potenciálján is vizsgálódnunk kellene. Így reggelente kerékpárral a szegedi vágóhídra jártam kis borjúszívek beszerzése miatt. Ezeket speciális oxigenizált tápoldatban szállítottam a híres Dóm téri épületben lévő szív-elektrofiziológiai laboratóriumunkba. Erőfeszítéseinket siker koronázta: 1973 nyarán elsőként sikerült hazánkban borjúszív Purkinje-rostjaiból intracelluláris akciós potenciálokat regisztrálni (4) majd rajtuk a magas FFA-szint direkt hatásait az elsők között tanulmányozni (1. ábra).

A borjúszív Purkinje-rost intracellulárisan regisztrált akciós potenciálján (1. ábra) az octanoat $(2,4 \mathrm{mmol} / \mathrm{l})$ hatására észlelt változások közül legfeltủnőbb az akciós potenciál időtartamának markáns rövidülése volt. Ezzel egy időben a repolarizáció korai, gyors fázisa rendkívül kifejezetté vált. A depolarizáció maximális sebessége majdnem a felére csökkent. A kísérletes időtartam alatt a membránpotenciál nem változott, míg az akciós potenciál amplitúdója mérsékelten csökkent. A felvételeken az ingerbetörés és az intracelluláris akciós potenciál közötti szakasz növekedése alapján jól megfigyelhető az is, hogy az octanoat az ingerületvezetés idejét megnyújtotta. Az octanoat hatása nagyrészt reverzibilisnek bizonyult, mivel a kontroll tápoldattal végzett kimosást követően az említett paraméterekben kifejezett helyreállási tendencia volt észlelhető (4). Hasonló hatásokat tapasztaltunk kutyaszív izolált jobb kamrai distalis ingerületvezetö rendszerén is, ahol az ingerületvezetés megnyúlása, késéses elsősorban a Purkinje-rostokon belül jött létre, kevéssé a Purkinje-rost-kamraizomrost junkcióban. Ezekböl a vizsgálatokból azt a következtetést vontuk le, hogy a magas FFA-szint képes az ép Purkinje-rost elektromos aktivitását mélyrehatóan befolyásolni (5).

Később kimutattuk a prostaglandin prekurzor hoszszú szénláncú telítetlen zsírsavaknak (pl. arachidon sav) az előzőektől eltérő direkt szívhatásait (6). A zsírsav-hipotézis experimentális vizsgálatából, illetve annak klinikai adatokkal kiegészített eredményeiből védtem meg az MTA kandidátusi értekezésemet (1982) (7). 


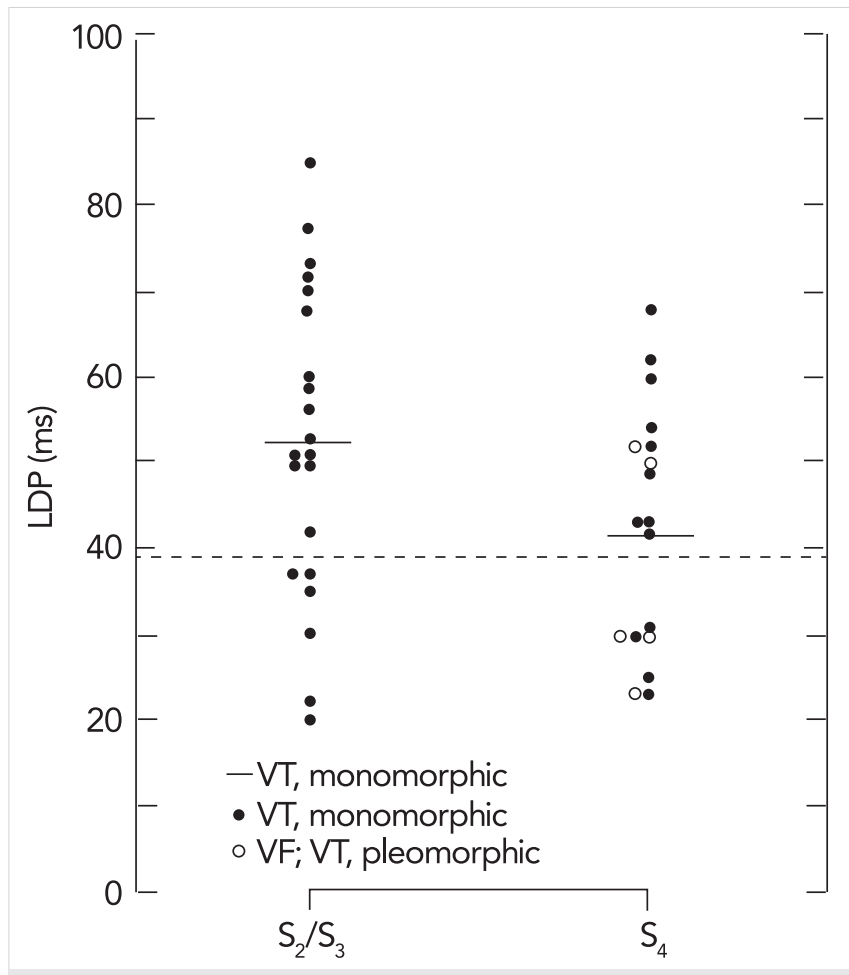

2. ÁBRA. Összefüggés a kamrai utópotenciál időtartama és a tartós kamrai tachycardia és/vagy kamrafibrilláció kiváltásához szükséges extrastimulus száma között koronáriabetegeken. (LPD = kamrai utópotenciál időtartama a filterezett QRS-komplex $<40 \mu \mathrm{V}$ amplitúdójánál. Kóros LPD [kamrai utópotenciál] [ $\geq 39 \mathrm{msec}$ - szaggatott vonal.) A kamrai utópotenciál időtartama szignifikánsan hosszabb az egyes és kettős extrastimulussal indukálható betegcsoportban a hármas extrastimulussal indukálható betegcsoporthoz képest $(p<0,025)$

\section{Gottsegen György Országos Kardiológiai Intézet (GOKI), Budapest (1976-)}

Mivel mindig is klinikus szerettem volna lenni, a családi hagyományokat folytatni, ezért medikus korom óta tartó vonzalmamnak, érdeklődésemnek engedve 1976-ban prof. dr. Szekeres László nagylelkủ ajánlására az új Országos Kardiológiai Intézet Kardiológiai Osztályára kerültem Budapestre. A belgyógyászat és a kardiológia elsajátítása mellett hamar megtanultam a szívkatéterezési technikákat és a koronarogáfiát, a sok éves koronária-őrzős beosztásban pedig a bed-side kardiológiai beavatkozásokat. 1977-ben hárman (dr. Veress Gábor, dr. Szatmáry László kollégáimmal) szív-elektrofiziológiai munkacsoportot alakítottunk. Célul tüztük ki, hogy Scherlag és munkatársai (1969) (8), Damato és Lau (1970) (9), Narula (1975) (10) munkáin alapuló, a korszerú klinikai szív-elektrofiziológia vizsgálómódszereit bevezetjük az országos intézetben. A következő évtől (1978. január) már nagy számban végeztünk rutinszerüen intrakardiális szív-elektrofiziológiai vizsgálatokat (EPS). Az EPS nagy segítséget nyújtott a szív ritmus- és/vagy inge- rületvezetési zavarainak, gyógyszeres és/vagy elektromos kezelésének a megválasztásában.

1985-ben a hirtelen szív(aritmia)halállal foglalkozó budapesti szimpóziumi közös szereplésünk, előadásom után prof. dr. B. Lown-tól meghívást, Harvard Egyetemi ösztöndíjat kaptam a híres bostoni kardiológiai klinikára. A Lown-klinikán évente 8-10 nemzetközi fellow dolgozott forgórendszerben a világ minden részéről. $A$ klinikai munka mellett föként az antiaritmiás gyógyszerek hatékonyságát tanulmányoztam, jobb kamrai extrastimulációs módszerekkel. Az ösztöndíj lejárta után 1986-87-ben Chicagóban (Rush-Presbyterian Med. Univ., St. Luke's Med. Cent.) kaptam kardiológiai ún. fellowship munkát. Itt a magyar származású prof. dr. $P$. Denes mellett a jelátlagolt-EKG (SA-EKG) paraméterek és az EPS során kiváltható kamrai tachycardiák/kamrai fibrillációk összefüggéseit kutattuk. Kimutattuk, hogy a kamrai utópotenciál időtartama összefüggésben van a tartós kamrai tachycardia/kamrafibrilláció elektromos ingerléssel való kiválthatóságával (2. ábra), valamint a monomorf kamrai tachycardia ciklushosszával is (11). Később az amiodaron szívhatásainak kialakulását tanulmányoztuk SA-EKG-val, összehasonlítva a kamrai utópotenciál tulajdonságait a szív-elektrofiziológiai paraméterekkel (12). Az ugyancsak itt dolgozó CPI/Guidant cég későbbi orvosigazgatójával, dr. R. Hauser-rel együtt pedig részt vettem az első 25 ICD akkoriban még thoracotomiás chicagói implantációjában $(13,14)$. Sok tapasztalattal, új módszerekkel megismerkedve 1987 végén utaztam haza Budapestre.

\section{Malignus WPW-szindróma aritmia-sebészeti kezelése (1990)}

H.K. 39 éves nő 1990-ben került felvételre 1979 óta ismert WPW-szindróma, keskeny és széles QRS-tachycardia, kardiogén sokkba torkolló pitvarfibrillációk miatt (25 hospitalizáció, 17 elektromos kardioverzió). Az antiaritmiás gyógyszerek és kombinációik mind hatástalannak bizonyultak, a magas kamrai frekvenciájú (200-240/min) gyakori ritmuszavarok miatt terhessége is megszakadt, állandó félelem mellett élt. Felvétele után stabil állapotban EPS-t végeztünk, amely igen alacsony refrakteritású $(230 \mathrm{msec})$ jobb oldali, posterior AV-bypass köteget igazolt. Az akkoriban külföldön induló (1989) transzkatéteres, rádiófrekvenciás ablációhoz szükséges eszközeink, berendezéseink ekkor még nem voltak meg. Ugyanakkor az intraoperatív, szívsebészeti aritmiamútét kellékeit 1990 tavaszán sikerült már beszereznünk (speciális gyürü- és nyeles elektródák, kryoablátor, mobilis regisztráló stb.), sőt már nyárra előtanulmányokat (intraoperatív, epikardiális, intrakardiális elektrogrammok regisztrálása, térképezés, elektromos ingerlés stb.) is végeztünk szívmütétre kerülő betegeken. A súlyos eset miatt szívsebész kollégámmal (dr. Richter T.) együtt direkt aritmiaműtét (a Kent-köteg kryoablációja, incíziója) elvégzése mellett döntöttünk (1990. 06. 25.). Lehetőségünk lett vol- 
na még az AV-junkció direkt katéteres DC ablációjára, amelyből már korábban is végeztünk néhány beavatkozást ultimum refugiumként. Ezt azonban - a kialakított AV-blokk miatt - pacemaker-implantációnak kell követnie, amely betegünk életminőségét csökkentette volna. Median sternotomia után sinusritmusban, majd pitvari, illetve kamrai elektromos ingerléssel az AV-sulcust körbejárva elektromos térképezést végeztünk a rendellenes AV-bypass köteg intraoperatív lokalizálására (jobb oldali, hátsó AV-bypass köteg). Szívmotor-támogatás mellett normotermiában a bemért ponton elvégeztük a kryoablációt (-60 C ${ }^{\circ}, 2,5$ perc) és az incíziót. Ekkor a kamrai preexcitáció EKG-képe megváltozott: a P-R-távolság megnyúlt, a QRS-komplexus keskennyé vált. Ezután stabil keringés mellett az extrakorporális keringés leállása, majd a sternotomia zárása történt. Szövődmény nem volt. Az aritmiaműtét eredményességét posztoperatív EPS-sel is ellenőriztük: normális supra-His, intra- és infra-His ingerületvezetést tapasztaltunk anterográd és retrográd, a jobb pitvarból, illetve a jobb kamrából szupraventrikuláris tachycardiát elektromos stimulációval kiváltani többé már nem lehetett. A beteget antiaritmiás gyógyszeres kezelés nélkül hazabocsátottuk, később zavartalan terhesség után gyereket szült (15). A transzkatéteres ablációk elindulásáig
(1994) még öt sikeres aritmiamütétet végeztünk súlyos WPW-szindrómás betegeken.

\section{Az első hazai implantábilis kardioverterer defibrillátor (ICD) készülékek alkalmazása (1992, 1997)}

$A z$ első hazai ICD implantációját éppen 25 évvel ezelőtt 1992. január 8-án végeztük el a GOKI-ban (16).

K.Z. 42 éves dilatatív cardiomyopathiás férfi gyors frekvenciájú (200-240/min) monomorf kamrai tachycardia, illetve kamrafibrillációk miatti négy sikeres reanimáció után került 1991 végén átvételre. Az antiaritmiás gyógyszerek hatástalannak bizonyultak. A posztreanimációs állapot rendezése után koronarográfiát (negatív) és EPS-t (továbbra is könnyen kiváltható, gyors, monomorf kamrai tachycardia) végeztünk. A bal kamrai szisztolés funkció jelentősen csökkent volt (EF: 28\%). Ezt követően személyes kapcsolatok segítségével, OEP-támogatás híján, a Medtronic cég adományából származó 7217/B típusú, nonthoracotomiás transzvénás és szubkután elektródás ICD (VVICD) szekunder prevenciós implantációjára (szívsebész: dr. Richter T.) került sor. Az ICD intraoperatív kipróbálása sikeres volt, a defibrillációs elektromos ingerküszöb megfelelőnek bizonyult (3. ábra). A posztoperatív szakban

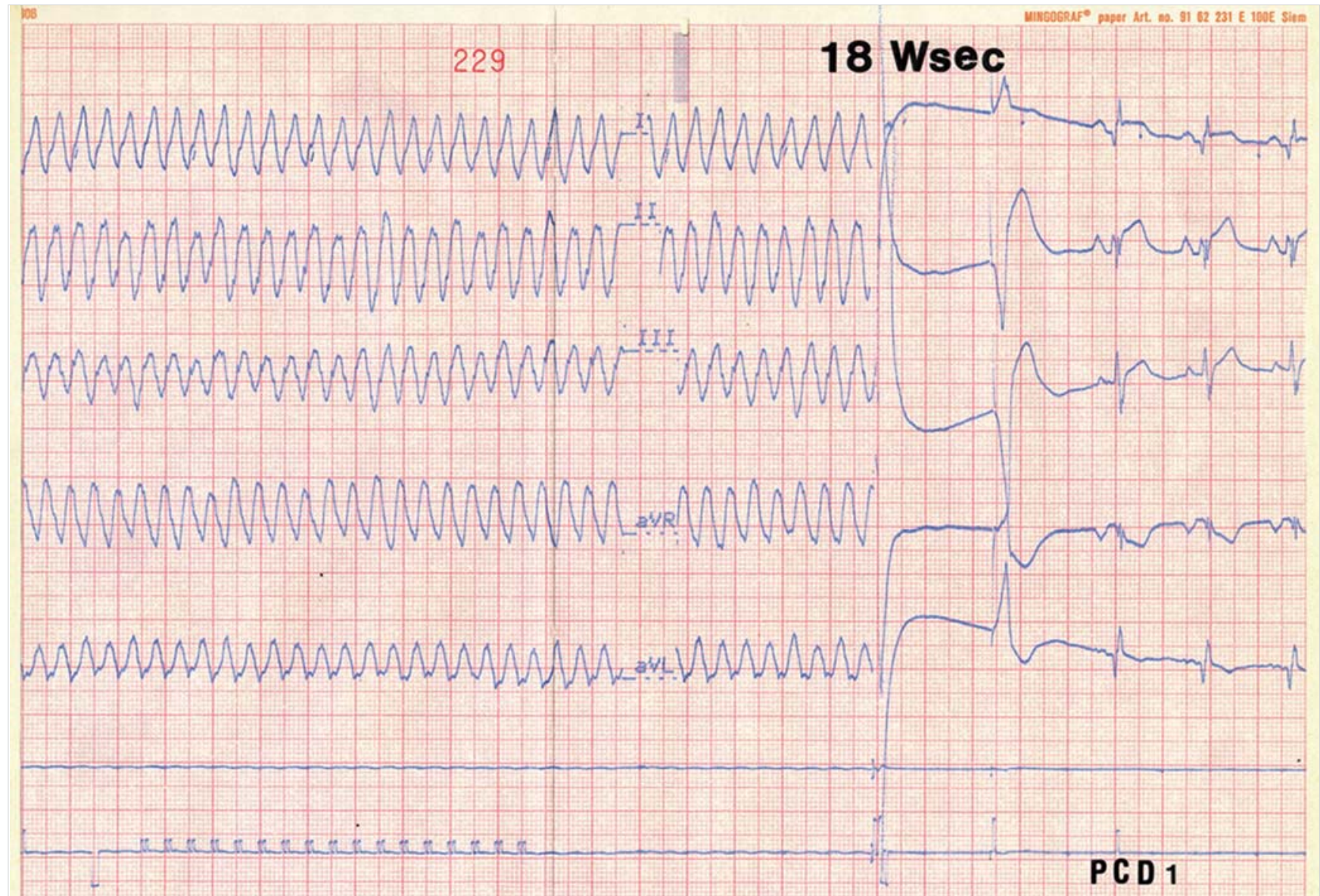

3. ÁBRA. Intraoperatív EKG-felvétel a Medtronic 7217/B implantációja kapcsán. (A 18 Joule sikeresen szüntette meg a kiváltott kamrafibrillációt. EKG: standard végtagi elvezetések, $1 \mathrm{mV}=10 \mathrm{~mm}, 25 \mathrm{~mm} / \mathrm{sec}$. PCD: pacemaker-kardioverter-defibrillátor) 
a generátor felett seroma alakult ki, amely kezelésre rendeződött. Az első ICD sikeresen terminált 16 kamrai tachyaritmiát az utánkövetése során. A beteget hazabocsátottuk, de 1992. áprilisban ismét felvételre került, majd befolyásolhatatlan szívelégtelenségben sajnos elhunyt. A nagy értékű első ICD-explantációra került, majd resterilizálása után a Medtronic cég, az etikai bizottság és következő ICD-re váró beteg jóváhagyásával, új elektródokkal 1993-ban ismét implantációra került. Az első ICD a második betegnél még hosszú ideig eredményesen működött. Az ICD-reimplantációt a PACE-ben is leközöltük (17), mivel hasonló reimplantációra addig még nem került sor.

Az első kétüregű ICD (DDICD) (CPI/Guidant Ventak AVII DR 1821) hazai implantációját 1997. nov. 21-én végeztük el a GOKI-ban (18). Egy aritmogén jobb kamrai dysplasiás (ARVD-s) fiatalembernél primer prevenciós indikáció alapján történt a DDICD implantációja, társuló intermittáló Mobitz II. AV-blokkja miatt (fiútestvére boncolással igazolt ARVD-s hirtelen szív(aritmia)halálban halt meg egy szegedi kollégiumban, a szív MRI-vizsgálata neki is ARVD-t igazolt). A 20 éve ICD-implantált, ARVD-s beteg számos generátorcsere után jelenleg is jól van, az ICD ismételten működött.

Transzkatéteres rádiófrekvenciás ablációval kezelt elsó hazai WPW-s beteg (1994)

A GOKI-ban 1994 nyarán indult el a szívritmuszavarok transzkatéteres rádiófrekvenciás ablációs programja alapítványi anyagi támogatással. A hazai program beindulásáig súlyos betegeink ablációs kezelését - tanulási célból is - külföldi centrumokban (Bécs, Hamburg, Maastricht) a külföldi kollégákkal együtt végeztem.

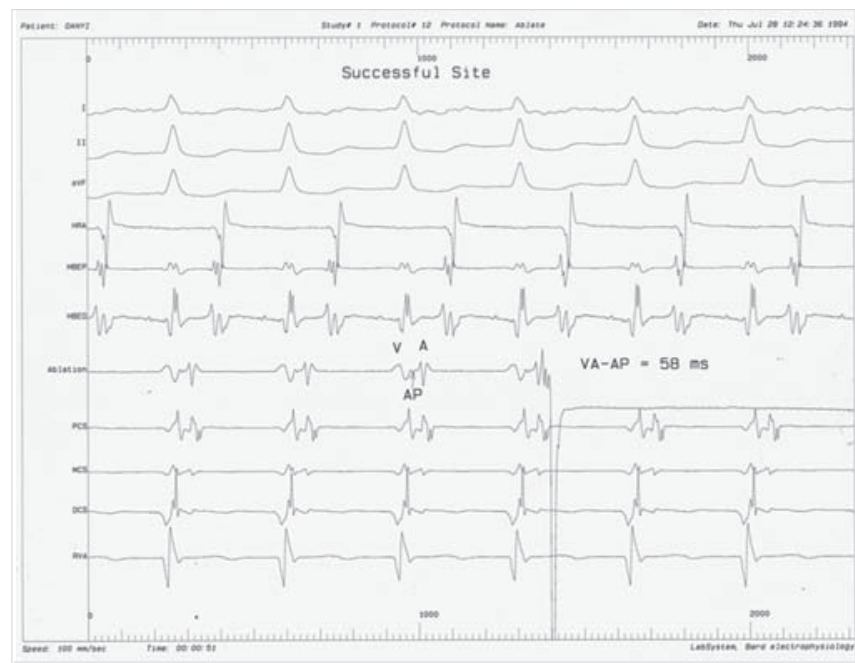

4. ÁBRA. D.B. szív-elektrofiziológiai vizsgálata során készült felvétel a „sikeres helyről”. (A felvétel az elektrostimulációval kiváltott orthodrom AVRT alatt készült. A sikeres helyen elvégezve az ablációt a bal posterior köteg retrográd vezetése retrográd blokkal az ablációs kezelés után 6 msec-ra megszűnt. Az ablációs elektródán felvett elektrogrammon jól megfigyelhető a bypass köteg potenciál.)

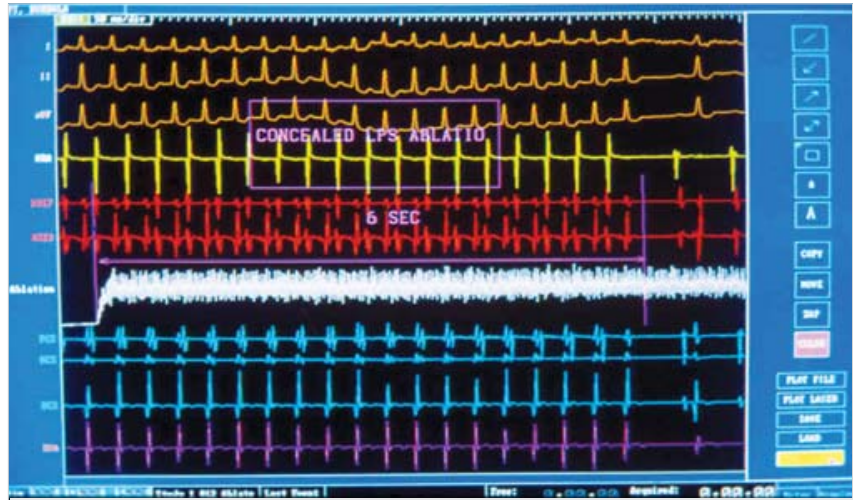

5. ÁBRA. D.B. ablációs kezelése során készült felvétel. (Az ablációs kezelés hatására jól látható az AVRT és a bypass köteg vezetés megszűnése)

D.B. 44 éves, concealed WPW-s nőbeteg gyakori gyógyszer-rezisztens orthodrom AV-reentry tachycardiák (AVRT-k) (gyakori sürgősségi iv. ellátás, elektromos kardioverzió - ECV háromszori igénye) miatt került első hazai ablációs kezelésre. A bal oldali AV-bypass köteg rádiófrekvenciás ablációjára transzaortikus behatolásból került sor (1994. július 28.) (4. ábra). A beavatkozás sikeres volt, az abláció után a köteg vezetése megszűnt (5. ábra), az AVRT-t kiváltani többé nem lehetett. Szövődmény nem volt (19). A beavatkozás óta antiaritmiás gyógyszert nem kellett szednie, AVRT nem fordult elő, a beteg 15, illetve 20 éves utánkövetéseiről beszámoltunk, a beteg szívritmuszavart tekintve panaszmentes (20).

1994-től 2012-ig mintegy 300 WPW-s beteg sikeres ablációs kezelését végeztük el, komolyabb szövődmény két esetben fordult elő (perikardiális tamponád, inferior ST-eleváció), amelyek kezelésre rendeződtek.

\section{AV-nodális reentry tachycardia (AVNRT)} első hazai transzkatéteres, rádiófrekvenciás ún. Iassú-pálya ablációs kezelése (1995) J.I-né 50 éves nő igen gyakori, gyógyszer-rezisztens keskeny QRS-tachycardiák, AVNRT-k miatt (72 sürgősségi iv. ellátás, $10 \mathrm{ECV}$ ) került felvételre, majd transzkatéteres rádiófrekvenciás ablációs kezelésre (1995. január 05.). Az EPS típusos AVNRT-t (slow-fast típus) igazolt. Emiatt direkt, ún. lassú-pálya elektromos modifikációt végeztem a $\mathrm{KOCH}$-háromszögben, amely után az AVNRT-t kiváltani többé már nem lehetett. Szövődmény nem volt. A beteg antiaritmiás gyógyszert nem szed, a beavatkozás óta AVNRT nem fordult elő. A nő szívritmuszavart tekintve jelenleg is panaszmentes, a 15 és a 20 éves utánkövetéseiről beszámoltunk (20, 21, 22).

Polgár és munkatársai (23) 1994-ben beszámoltak egy PSVT-s beteg transzkatéteres rádiófrekvenciás ablációs kezeléséről. Azonban ők nem lassú-pálya ablációt végeztek, hanem AV-csomó-ablációt, amely után harmadfokú AV-blokk alakult ki, amelyet pacemaker-implantáció követett. 
Az első hazai AVNRT lassú-pályás ablációs kezelése óta 1995-2012 között mintegy 400 hasonló beavatkozást végeztem, számottevő szövődmény nem fordult elő, az első száz esetben öt alkalommal volt szükség AV-vezetési zavar miatt pacemaker implantációjára.

\section{Megbeszélés}

A klinikai szívritmuszavarok kezelésének elvei, stratégiája és mindennapos gyakorlata is jelentős változáson ment keresztül az elmúlt évtizedekben. Elöretört és jelenleg is vezető helyen van az ún. non-farmakológiai kuratív terápia (transzkatéteres rádiófrekvenciás abláció, kryoabláció), valamint kamrai szinten primer és szekunder prevenciós indikációval az ICD-implantációs kezelés. Az antiaritmiás gyógyszeres kezelés korábbi dominanciája jelentősen mérséklődött, csökkent. Az antiaritmiás farmakoterápia háttérbe szorulását részint az ablációs kezelés sikeressége okozta, részint pedig néhány újabb antiaritmiás gyógyszer (pl. azimilid, dronedaron) kudarca, elvérzése is (24). Ehhez hozzájárult még az antiaritmiás szerek nem kívánt lehetséges káros mellékhatása (torsadogén hatások, proaritmia, kardiodepresszív hatás stb.), az extrakardiális toxicitás lehetősége is, valamint a "safety first" elvének az alkalmazása $(25,26)$. A gyógyszerkutatás is folytatódik, új lehetőség pl. az antiaritmiás (etripamil) orrspray alkalmazása PSVT-ben. Az alapbetegség megfelelő kezelésének a fontossága, a gyakori elektrolit- $(\mathrm{K}, \mathrm{Mg})$ szint kontroll szükségessége az évek során nem változott. A szívritmuszavarok (WPW, kamrai tachycardia) kezelésére korábban kidolgozott ún. aritmiasebészeti mód- szerek az abláció és az ICD sikeressége miatt sokat veszítettek korábbi jelentőségükből. Ezek a mütétek jelenleg egyedi, heart-team döntés alapján, általában más okból végzett szívsebészeti mütétekhez társulnak. Manapság a korszerủ ritmuszavar-ellátás elemeit széles palettáról (gyógyszer/abláció/pacemaker/lCD/ CRT/elektromos kardioverzió) lehet kiválasztani. A jövő azonban vitathatatlanul az ablációs kezelés, elektroanatómiai térképezés csúcstechnológiájának a rohamos, nagyléptékủ fejlődése. Természetesen szükség van továbbra is hatékony, biztonságos, lehetöleg pitvar- vagy kamra-specifikus antiaritmiás gyógyszerekre is, akár önállóan, akár más kezelési modalitással (ún. hibrid kezelés, pl. pacemaker/ICD+amiodaron terápia) együtt. A hazai gyakorlatban a betegek nagy száma miatt is, még mindig az antiaritmiás gyógyszeres kezelés jelenti a szívritmuszavar-ellenes kezelés első vonalát. Az antiaritmiás kezelés modalitásait, indikációit 2017ben a 6 . ábra foglalja össze.

A szívritmuszavarok kezelésének alapja, sine qua nonja a pontos diagnózis. A helyes terápiás döntés kialakításához azonban számos klinikai tényező komplex ismerete fontos: a kórelőzmény, familiaritás (genetikai markerek), a klinikai kép, a tünetek és súlyosságuk, strukturális/elektromos szívbetegség, szívizom-iszkémia jelenléte vagy hiánya, a bal kamrai szisztolés funkció, a ritmuszavar alatti és a sinusütem melletti 12 elvezetéses EKG-k elemzése, korábbi antiaritmiás gyógyszerek hatékonysága/mellékhatásai, előző beavatkozások eredményei stb. Indikáció esetén fontos a standard, rutin EPS eredménye által szolgáltatott pontos diagnózis (pl. AVNRT vagy AVRT?), amelyet az abláció egy ülésben történő elvégzése követ (24).

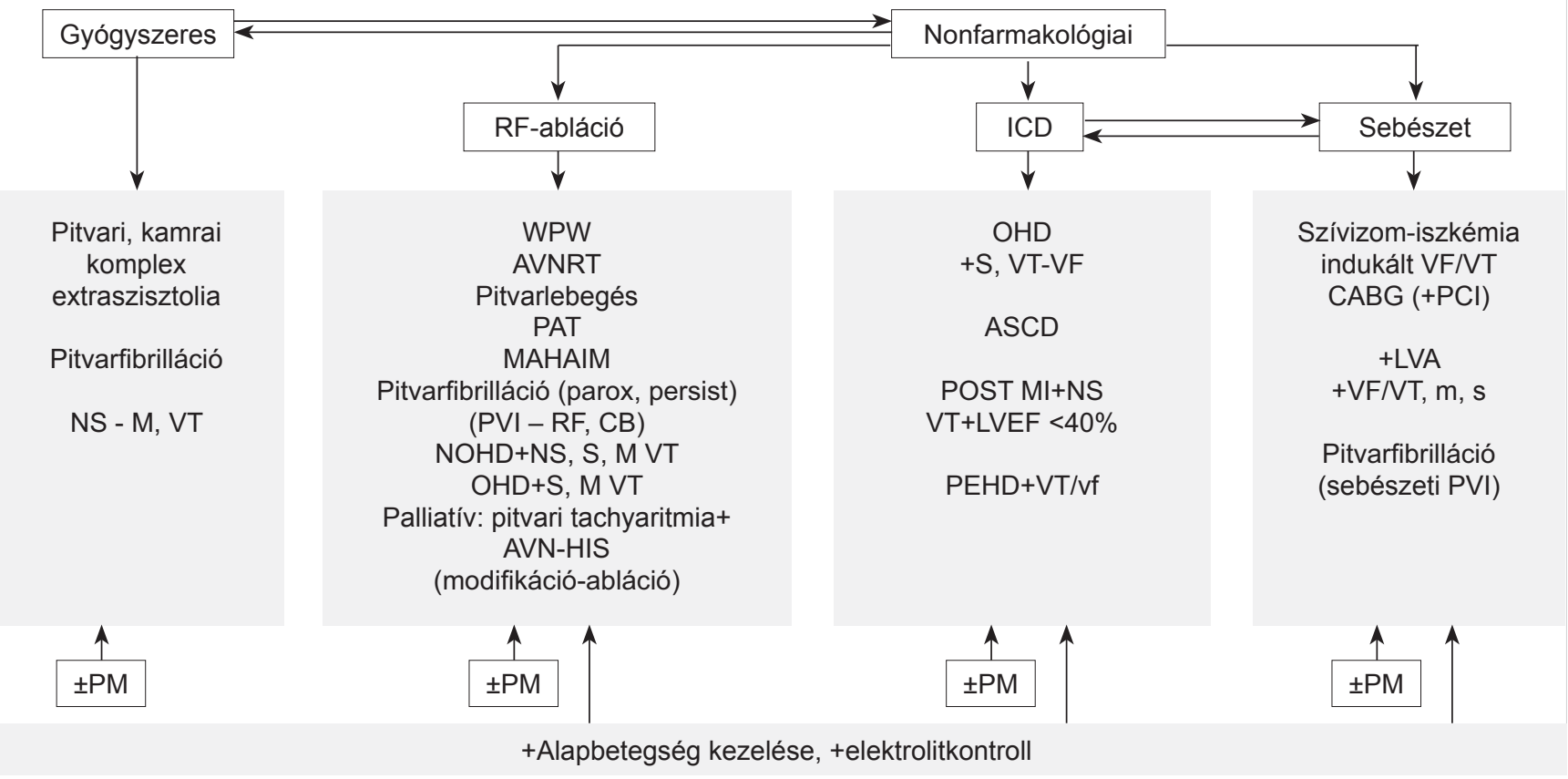

6. ÁBRA. Antiaritmiás kezelés 2017-ben (ASCD: aborted sudden cardiac death, LVA: left ventricular aneurysm, NOHD: no organic heart disease, OHD: organic heart disease) 
A közleményben bemutatott első hazai beavatkozások (WPW-sebészet: 1990; ICD-implantáció: 1992, 1997; WPW transzkatéteres ablációs kezelése: 1994; AVNRT lassú-pálya transzkatéteres ablációs modifikációja: 1995) jól példázzák a klinikai szív-elektrofiziológia/aritmológia rövid időn belüli, gyors hazai fejlődését. Mindegyik beavatkozás alapja azonban az EKG-diagnosztika és az EPS széles körü, mélyreható, pontos ismerete. A szegedi Gyógyszertani Intézetben elsajátított extra- és intracelluláris mikro szív-elektrofiziológia kitűnő alapul szolgált számomra az EPS-ek elvégzéséhez, az antiaritmiás gyógyszerek hatásainak, majd a pacemakerek/ ICD-k működésének a megértéséhez. A korán belém táplált tudományos szemlélet, gondolkodás pedig nagy segítségemre volt a folyamatos klinikai kutatásokban.

Hálás vagyok a sorsnak, kitűnő munkatársaimnak, az EP-teamnek, kollégáimnak, támogató klinikai főnökeimnek, barátaimnak itthon és külföldön, hogy olyan időszakokban lehettem kardiológus/aritmológus, amikor személyesen is átélhettem a klinikai szív-elektrofiziológián alapuló beavatkozások (aritmiamütét, ICD-implantáció, transzkatéteres abláció) hazai nagyívű, csodás, gyógyító fejlődését. Ezen a rögös, de szép pályán első tanítómesterem a nagyszerü, mindig segítőkész, különleges eleganciájú és stílusú, világszerte kiemelkedően elismert prof. dr. Papp Gyula akadémikus indított el.

\section{Irodalom}

1. Papp Gy. Számvetés (Jubileumi Kiadvány) (szerk. Varró A.) Szeged: Szegedi Tudományegyetem Kiadó; 2007.

2. Kurien VA, Oliver MF. A metabolic cause for arrhythmias during acute myocardial infarction. Lancet 1970; 1: 813-815. https://doi.org/ 10.1016/S0140-6736(70)92412-8

3. Borbola J, Papp Gy, Szekeres L. A lipid anyagcsere egyes metabolitjainak hatása a szívizom néhány elektrofiziológiai paraméterére és kontraktilitására. Kísérletes Orvostud 1974; 26: 20-31.

4. Borbola J, Papp Gy, Szekeres L. Effect of octanoate on the electrical activity of Purkinje fibres. Experientia 1974; 30: 262-264.

5. Borbola J, Papp Gy, Szekeres L. Magas zsírsav szint hatása a jobb kamra izolált distális ingerületvezető rendszerére. Card Hung 1975; 4: 121-134.

6. Borbola J, Süsskand, Siess M, et al. The effect of arachidonic acid in isolated atria of guinea pigs. Eur J Pharmacol 1977; 41: 27-36. https://doi.org/10.1016/0014-2999(77)90367-3

7. Borbola J. Zsírsavak és elektrofiziológiai tényezők szerepe a szívizominfarktust követő ritmuszavarok kialakulásában. Budapest: MTA Kandidátusi értekezés; 1982

8. Scherlag BJ, Lan SH, Helfant RH, et al. Catheter technique for recording His bundle activity in man. Circulation 1969; 39: 13-18. https://doi.org/10.1161/01.CIR.39.1.13
9. Damato AN, Lau SH. Clinical value of the electrogram of the conduction system. Progr Cardiovasc Dis 1970; 13: 119-134. https://doi. org/10.1016/0033-0620(70)90005-8

10. Narula OS. His bundle electrocardiography and clinical electrophysiology. Philadelphia: FA. Davis Comp; 1975. https://doi. org/10.7326/0003-4819-83-6-916_2

11. Borbola J, Ezri MD, Denes P. Correlation between the signal-averaged electrocardiogram and electrophysiologic study findings in patients with coronary artery disease and sustained ventricular tachycardia. Am Heart J 1988; 115: 816-824. https://doi.org/ 10.1016/0002-8703(88)90884-8

12. Borbola J, Denes P. Oral amiodarone loding therapy I. The effect on serial signal-averaged electrocardiographic recordings and the QT $_{c}$ in patients with ventricular tachyarrhythmias. Am Heart J 1988; 115: 1202-1208. https://doi.org/10.1016/0002-8703(88)90009-9

13. Borbola J, Denes P, Ezri MD, et al. The automatic implantable kardioverterer-defibrillator. Clinical experience, complications, and follow-up in 25 patients. Arch Intern Med 1988; 148: 70-76. https:// doi.org/10.1001/archinte.1988.00380010074007

14. Borbola J, Denes P, Hauser RG, et al. Early and late electrophysiologic observations in patients with automatic implantable kardioverterer-defibrillator. Pace 1989; 12: 1254.

15. Borbola J, Richter T, Árvay A. Malignus WPW-szindróma aritmia-sebészeti kezelése. Magy Belorv Arch 1992; 45(Suppl 2): 86.

16. Richter T, Borbola J, Árvay A. A beültethető pacemaker-kardioverterer-defibrillátor. Orv Hetil 1995; 136: 295-298.

17. Borbola J, Richter T. Successful reuse of a pacemaker-kardioverterer-defibrillator. Pace 1995; 18: 1155.

18. Borbola J, Richter T. Implantábilis kardioverterer-defibrillátor + DDD pacemaker készülék első hazai implantációja. Card Hung 1998; 27(Suppl 1): 71.

19. Borbola J, Hajdú E. A WPW szindróma elektrofiziológiája és transzkatéteres rádiófrekvenciás ablációs kezelése. Card Hung 1996; 25(1): 47-51.

20. Borbola J, Hajdú E. Transzkatéteres, rádiófrekvenciás ablációval kezelt első PWP-s és AV-nodális reentry tachycardiás betegek 20 éves utánkövetése. Card Hung 2016; 46: F20.

21. Borbola J. Transcatheter laser ablation of AV-nodal reentrant tachycardia-do we really need a newer energy source? Eur Heart J 1997; 18: 357-358. https://doi.org/10.1093/oxfordjournals.eurheartj.a015251 22. Borbola J. AV-nodális reentry tachycardia. In: Klinikai szív-elektrofiziológia és aritmológia (szerk. Fazekas T, Papp Gy, Tenczer J.) Budapest: Akadémiai Kiadó; 1999. p. 236-261.

23. Polgár $\mathrm{P}$, et al. Gyógyszerrezisztens supraventriculáris tachycardia kezelése az AV junkció rádiófrekvenciás ablációjával. Orv Hetil 1994; 135: 1859-1861.

24. Borbola J. Szívritmuszavarok diagnosztikája és kezelése. Budapest: EGIS CV klub; különkiadás, 2004.

25. Lengyel C, Varró A, Tábori K, et al. Combined pharmacological block of $\mathrm{IK}_{\mathrm{R}}$ and $\mathrm{IK}_{\mathrm{S}}$ increases short-term QT interval variability and provokes torsades de pointes. Brit J Pharmacol 2007; 151: $941-$ 951. https://doi.org/10.1038/sj.bjp.0707297

26. Camm J. Safety consideration in the pharmacolological management of atrial fibrillation. Int J Cardiol 2008; 127: 299-306. https:// doi.org/10.1016/j.ijcard.2007.11.006 